\title{
Improvement of Science Learning Outcomes Ruminant Animal Destruction System Materials Through Google Meet Media for Students Of Class V SD Negeri 2 Kedunggede
}

\section{Nurdiyah Sampurni}

SD Negeri 2 Kedunggede Kecamatan Banyumas nurdiyahsampurni@gmail.com

\section{Article History}

accepted 14/11/2020

\begin{abstract}
The purpose of this research was to improve the science learning outcomes of Ruminant Digestive System material through Google Meet media for fifth grade students of SD Negeri 2 Kedunggede. The research conducted was a Classroom Action Research (CAR) in three cycles, with each cycle consisting of one meeting. The stages of each cycle are planning, implementing, observing and reflecting. Each meeting is evaluated at the end of the lesson to find out the progress of students. In the first cycle, students who completed after conducting an evaluation at the end of the lesson were $61.5 \%$. In the second cycle, students who completed after evaluating at the end of the lesson were $76.9 \%$. In cycle III students who completed after conducting an evaluation at the end of the lesson were $80.8 \%$. These results indicate that the use of Google Meet media can improve student learning outcomes, especially the science muple of the Ruminant Digestive System material for Grade V students at SDN 2 Kedunggede.

Keywords: learning outcomes, google meet, science
\end{abstract}

\begin{abstract}
Abstrak
Tujuan dari penelitian ini adalah untuk meningkatkan hasil belajar IPA materi Sistem Pencernaan Hewan Ruminansia melalui media Google Meet bagi siswa kelas V SD Negeri 2 Kedunggede. Penelitian yang dilakukan adalah Penelitian Tindakan Kelas (PTK) sebanyak tiga siklus, dengan setiap siklusnya terdiri dari satu pertemuan. Tahapan setiap siklusnya adalah perencanaan, pelaksanaan, observasi dan refleksi. Setiap pertemuan dilakukan evaluasi di akhir pembelajaran untuk mengetahui perkembangan peserta didik. Pada siklus I peserta didik yang tuntas setelah melaksanakan evaluasi di akhir pembelajaran sebesar $61,5 \%$. Pada siklus II peserta didik yang tuntas setelah melaksanakan evaluasi di akhir pembelajaran sebesar $76,9 \%$. Pada siklus III peserta didik yang tuntas setelah melaksanakan evaluasi di akhir pembelajaran sebesar $80,8 \%$. Hasil ini menunjukan bahwa penggunaan media Google Meet dapat meningkatkan hasil belajar peserta didik khususnya mupel IPA materi Sistem Pencernaan Hewan Ruminansia bagi siswa Kelas V di SDN 2 Kedunggede.
\end{abstract}

Kata kunci: hasil belajar, google meet, IPA

Social, Humanities, and Education Studies (SHEs): Conference Series https://jurnal.uns.ac.id/shes

p-ISSN 2620-9284

e-ISSN 2620-9292 


\section{PENDAHULUAN}

Pendidikan adalah suatu yang dilakukan dengan sadar oleh keluarga, masyarakat atau pemerintah melalui bimbingan, pengajaran, pembelajaran dan pelatihan yang berlangsung, baik dilakukan di sekolah maupun luar sekolah sepanjang hidup untuk mempersiapkan siswa agar dapat menjalankan perannya dalam lingkungan untuk masa yang akan datang.

Dalam UU RI No. 20 Tahun 2003 tentang Sistem Pendidikan Nasional, pasal 1 menjelaskan pendidikan adalah usaha sadar dan terencana untuk mewujudkan suasana belajar dan proses pembelajaran agar peserta didik secara aktif mengembangkan potensi dirinya untuk memiliki kekuatan spiritual keagamaan, pengendalian diri, kepribadian, kecerdasan, akhlak mulia, serta keterampilan yang diperlukan dirinya, masyarakat, bangsa dan negara. (Departemen Pendidikan Nasional, 2014).

Salah satu kebijakan dalam pendidikan yang diterapkan di Indonesia adalah dengan penggunaan kurikulum dua ribu tiga belas (KK 13). Kurikulum ini diharapkan dapat meningkatkan penalaran siswa pada tiap-tiap tingkat satuan Pendidikan. Pada pembelajaran di kelas menggunakan kurikulum 2013 siswa belajar untuk mencari sendiri segala sesuatu yang ada. Mereka harus aktif dan kreatif dalam pembelajaran. Pembelajaran ini memusatkan siswa sebagai sumber belajar bukan lagi seorang guru. Guru dalam hal ini hanya sebagai fasilitator. Namun, delapan bulan terakhir Indonesia diserang wabah covid 19 yang mengharuskan kegiatan pembelajaran dilaksankan dari rumah. Siswa belajar mandiri dibantu oleh kedua orang tua. Meskipun belajar dilaksanakan dari rumah, tujuan pendidikan haruslah tetap tercapai. Pembelajaran yang kondusif yaitu pembelajaran yang aktif, interakif, terjadi dua arah, semangat dan motivasi belajar tinggi, serta hasil belajar tinggi juga harus tetap dilaksanakan demi mencapai tujuan pendidikan tersebut. Akan tetapi, pada kenyataannya pembelajaran dalam jaringan (daring) sekarang ini menimbulkan berbagai permasalahan. Permasalahan yang dialami peneliti antara lain:

1. Pembelajaran daring yang selama ini diterapkan di SD Negeri 2 Kedunggede masih menggunakan media whatsapp grup, sehingga pembelajaran cenderung satu arah, kurang aktif dan kurang interaktif, masih banyak anak yang hanya melihat status/informasi saja.

2. Hasil pengamatan awal menunjukan bahwa siswa kelas 5 SD Negeri 2 Kedunggede belum memiliki semangat belajar yang tinggi yang mampu meningkatkan hasil belajar siswa.

3. Hasil belajar siswa masih rendah selama pembelajaran daring dengan menggunakan media whatsapp karena jumlah siswa yang dapat mencapai KKM pada muatan pelajaran IPA belum mencapai $70 \%$.

Berdasarkan permasalahan yang ada maka dilakukan Penelitian Tindakan Kelas (PTK). Menurut Arikunto, dkk, penelitian tindakan kelas merupakan suatu pencermatan terhadap kegiatan belajar berupa sebuah tindakan, yang sengaja dimunculkan dan terjadi dalam sebuah kelas secara Bersama. Sedangkan menurut Wardhani, dkk, Penelitian Tindakan Kelas adalah penelitian yang dilakukan oleh guru di kelasnya sendiri melalui refleksi diri dengan tujuan untuk memperbaiki kinerjanya sehingga hasil belajar siswa meningkat. Menurut Zainal Aqib dkk (dalam Suyadi 2012: 49) merumuskan langkah-langkah PTK sebagai berikut:

1) Tahap Perencanaan

Dalam perencanaan PTK, terdapat tiga dasar, yakni:

- Identifikasi masalah

- Analisis penyebab masalah dan merumuskannya

- Ide untuk memecahkan masalah

2) Tahap Acting (Pelaksanaan)

3) Tahap Observation (Pengamatan) 


\section{4) Tahap Refleksi}

Menurut Djamarah dan Zain (2010), hasil belajar ialah apa yang diperoleh siswa setelah dilakukan aktivitas belajar. Sedangkan menurut Dimyati dan Mudjiono (2006), hasil belajar ialah hasil yang dicapai dalam bentuk angka-angka atau skor setelah diberikan test hasil belajar pada setiap akhir pembelajaran. Selanjutnya, nilai yang diperoleh siswa menjadi acuan untuk melihat penguasaan siswa dalam menerima materi pelajaran. Menurut Bloom (dalam Suprijono 2013:6) hasil belajar mencakup kemampuan kognitif, afektif dan psikomotorik. Kemampuan kognitif terdiri dari knowledge (pengetahuan, ingatan); comprehension (pemahaman, menjelaskan, meringkas, contoh); application (menerapkan); analysis (menguraikan, menentukan hubungan); synthesis (mengorganisasikan, merencanakan); dan evaluating (menilai). Kemampuan afektif terdiri dari receiving (sikap menerima); responding (memberikan respon), valuing (nilai); organization (organisai); characterization (karakterisasi). Kemampuan psikomotorik meliputi initiatory, pre-rountie dan routinized.

Berbagai upaya peningkatan hasil belajar siswa telah dilakukan guru, namun belum mencapai hasil yang maksimal. Hal ini dikarenakan belum menggunakan media yang dapat meningkatkan motivasi dan keaktifan siswa yang nantinya juga akan meningkatkan hasil belajar siswa.Menurut Syaiful Bahri Djamarah dan Azwan Zain (2010:121) mengungkapkan bahwa media pembelajaran adalah alat bantu apa saja yang dapat dijadikan sebagai penyalur pesan agar tercapai tujuan pembelajaran. Menurut Azhar (2011) media pembelajaran adalah alat bantu pada proses belajar baik di dalam maupun diluar kelas, lebih lanjut dijelaskan bahwa media pembelajaran adalah komponen sumber belajar atau wahana fisik yang mengandung materi intruksional di lingkungan siswa yang dapat merangsang siswa untuk belajar. Sedangkan menurut Rayanda Asyar (2012: 8) mengemukakan bahwa media pembelajaran dapat dipahami sebagai segala sesuatu yang dapat menyampaikan atau menyalurkan pesan dari sumber secara terencana, sehingga terjadi lingkungan belajar yang kondusif dimana penerimanya dapat melakukan proses belajar secara efisien dan efektif. Menurut Dara Sawitri (2020) Google Meet bisa menjadi media alternatif untuk proses belajar mengajar. Google meet memiliki interface atau antarmuka yang unik dan fungsional dengan ukuran ringan serta cepat, mengedepankan pengelolaan yang efisien, mudah guna (user friendly) yang dapat diikuti semua pesertanya. Berdasarkan hasil kajian pustaka, peneliti akan menerapkan pembelajaran menggunakan media Google Meet untuk memperbaiki proses belajar dan meningkatkan hasil belajar siswa terhadap pembelajaran daring di SD Negeri Kedunggede 2.

\section{METODE}

Penelitian ini adalah penelitian tindakan kelas (PTK) yang dilaksanakan dalam dua siklus dengan menerapkan media Google Meet. Dalam setiap siklus meliputi tahap perencanaan (planning), pelaksanaan (acting), pengamatan (observing) dan refleksi (reflecting). Sumber data yang digunakan adalah sumber data primer yang bersumber dari subjek penelitian yaitu siswa kelas V SD Negeri 2 Kedunggede pada semester I tahun pelajaran 2020/2021. Data primer berupa nilai hasil belajar siswa kelas $V$ yang diperoleh melalui tes pada akhir tiap siklus. Teknik pengumpulan data yang dilakukan adalah berupa studi dokumen (absensi siswa, nilai rapor, dan nilai ulangan harian sebelum PTK), tes (nilai ulangan tiap siklus), dan observasi (dibantu oleh teman sejawat). Alat pengumpul data tes berupa soal tes dan non tes berupa lembar observasi. Analisis penelitian ini adalah analisis deskriptif kuantitafif dan kualitatif. Analisis deskriptif kuantitatif dilakukan berdasarkan hasil tes pengetahuan tiap siklus dengan mencari nilai rata-rata, nilai tertinggi dan terendah. Kemudian menganalisis rata-rata nilai tersebut dengan cara menggunakan analisis deskriptif komparatif, yaitu membandingkan nilai kondisi awal sebelum penelitian, nilai rata-rata siklus I, siklus II dan siklus III. Analisis deskriptif kualitatif dilakukan berdasarkan hasil observasi 
keterlibatan siswa dalam pembelajaran yang meliputi keberanian menjawab dan keaktifan siswa.

\section{HASIL DAN PEMBAHASAN}

Pada studi awal pembelajaran hanya menggunakan media whatsapp grup. Pada studi awal didapatkan 8 siswa tuntas dan 18 siswa tidak tuntas. Persentase ketuntasan adalah 30,8\% dan tidak tuntas $69,2 \%$ dengan rata-rata kelas 60,77. Dalam pembelajaran siklus I guru menggunakan media Google Meet untuk menyampaikan materi dan berinteraksi dengan siswa. Pada siklus I guru membagi siswa menjadi beberapa kelompok besar untuk melakukan diskusi dalam mengerjakan lembar kerja melalui whatsapp grup kelompok. Dari hasil pembelajaran pada kegiatan perbaikan siklus I diperoleh hasil yaitu siswa tuntas 16 siswa $(61,5 \%)$ dan tidak tuntas 10 siswa $(38,5 \%)$ dengan rata-rata kelas yang dicapai adalah 66,2 . Berdasarkan refleksi pada siklus I maka diputuskan untuk melanjutkan ke siklus II dikarenakan belum mencapai ketuntasan klasikal yang diharapkan

Pada pembelajaran siklus II guru masih menggunakan media Google Meet untuk menyampaikan materi dan berinteraksi dengan siswa. Pada siklus II guru membagi siswa menjadi kelompok-kelompok kecil untuk melakukan diskusi melalui whatsapp grup kelompok. Dari hasil pembelajaran pada kegiatan perbaikan siklus II diperoleh hasil siswa tuntas 20 siswa $(76,9 \%)$ dan tidak tuntas 6 siswa $(23,1 \%)$ dengan rata-rata kelas yang dicapai adalah 73,5. Berdasarkan refleksi pada siklus II maka diputuskan untuk melanjutkan ke siklus III karena hasil belajar dan rata-rata kelas yang dicapai hanya sedikit diatas target.

Pada siklus III guru menggunakan media Google Meet dan membagi siswa menjadi kelompok-kelompok kecil untuk melakukan diskusi melalui whatsapp grup kelompok. Dalam pembelajaran divariasikan dengan pemberian game yang dibuat melalui aplikasi wordwall online. Peneliti membagikan link permainannya melalui whatsaap kemudian siswa tinggal membuka link dan memainkan permainannya yang berisi soal-soal terkait materi sistem pencernaan hewan ruminansia. Dari hasil pembelajaran pada kegiatan perbaikan siklus III diperoleh hasil siswa tuntas 21 siswa $(80,8 \%)$ dan tidak tuntas 5 siswa $(19,2 \%)$ dengan rata-rata kelas yang dicapai adalah 75,8 .

Rekapitulasi ketuntasan siswa dalam jumlah maupun dalam persen dari studi awal, siklus I, siklus II dan siklus III dapat dilihat pada Tabel 1 maupun pada gambar 1 dan 2 berikut ini:

Tabel 1. Rekapitulasi Ketuntasan Siswa

\begin{tabular}{cccccccccc}
\hline \multirow{2}{*}{ No } & \multirow{2}{*}{ Ketuntasan } & \multicolumn{2}{c}{ Studi Awal } & \multicolumn{2}{c}{ Siklus I } & \multicolumn{2}{c}{ Siklus II } & \multicolumn{2}{c}{ Siklus III } \\
\cline { 3 - 9 } & & Jml & $\%$ & Jml & $\%$ & Jml & $\%$ & Jml & $\%$ \\
\hline 1 & Tuntas & 8 & 30,8 & 16 & 61,5 & 20 & 76,9 & 5 & 19,2 \\
2 & Tidak Tuntas & 18 & 69,2 & 10 & 38,5 & 6 & 23,1 & 21 & 80,8 \\
\hline
\end{tabular}

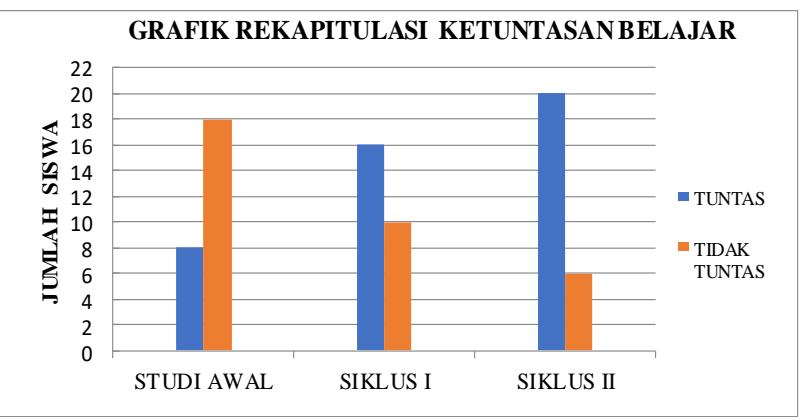

Gambar 1. Rekapitulasi Ketuntasan Belajar (dalam Jumlah) 


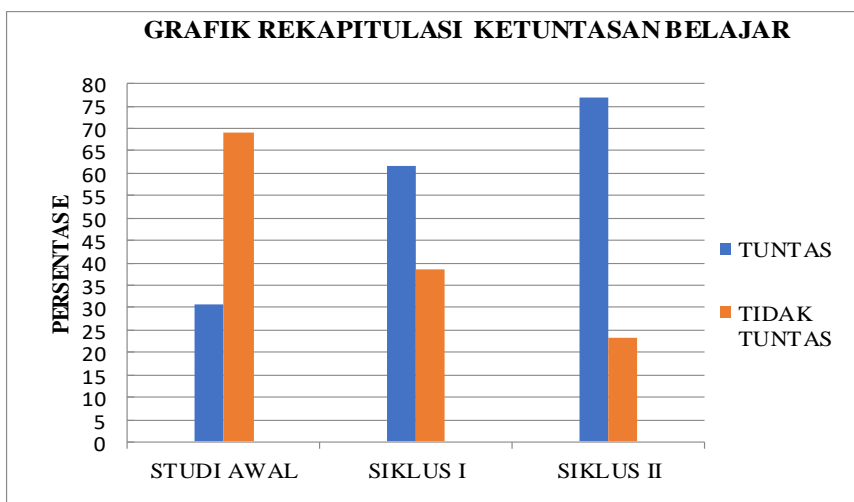

Gambar 2. Rekapitulasi Ketuntasan Belajar (dalam Persen)

\section{SIMPULAN}

Berdasarkan temuan hasil penelitian dan pembahasan yang telah dilakukaan, maka dapat diambil kesimpulan bahwa terjadi peningkatan hasil belajar IPA materi sistem pencernaan hewan ruminansia pada siswa kelas V SD Negeri 2 Kedunggede. Peningkatan ketuntasan belajar dari studi awal ke siklus I adalah 30,7 persen, dari siklus I ke siklus II adalah 15,4 persen dan dari siklus II ke siklus III adalah 3,9 persen. Hal ini menunjukkan bahwa penggunaan media Google Meet dapat meningkatkan keterlibatan siswa dalam pembelajaran yang pada akhirnya dapat meningkatkan hasil belajar IPA materi sistem pencernaan hewan ruminansia bagi siswa kelas V SD Negeri 2 Kedunggede.

\section{DAFTAR PUSTAKA}

Arikunto, Suharsimi, dkk. (2010). Penelitian Tindakan Kelas. Jakarta: Bumi Aksara Arsyad, Azhar. (2011). Media Pembelajaran. Jakarta : Rajawali Pers

Asyar, Rayandra. (2012). Kreatif Mengembangkan Media Pembelajaran. Jakarta: Gaung Persada Press

Depdiknas. (2004). Kerangka Dasar Kurikulum 2004.Jakarta

Djamarah, Syaiful Bahri dan Aswan Zain. (2010). Strategi Belajar Mengajar. Jakarta : PT Rineka Cipta.

Dimyati dan Mudjiono. (2006). Belajar dan Pembelajaran. Jakarta: PT Rineka Cipta

Suprijono, Agus. (2013). Cooperative Learning. Surabaya: Pustaka Belajar

Sawitri, Dara. (2020). Penggunaan Google Meet Untuk Work From Home Di Era Pandemi Coronavirus Disease 2019 (Covid-19). Jurnal Prioritas: Jurnal Pengabdian Masyarakat, Volume: 02, Nomor: 01.

Suyadi (2012). Panduan Penelitian Tindakan Kelas. Yogyakarta: Diva Press

Wardhani, I.G.A.K. \& Wihardit, K. (2012). Penelitian Tindakan Kelas. Jakarta: Universitas Terbuka. 